\title{
The Effect of Granulocyte Macrophage-Colony Stimulating Factor upon the Induction of Peripheral Blood Dendritic and Natural Killer Cells When Given Simultaneously with a Slow Continuous Doxorubicin Infusion
}

\author{
Arthur J. Weiss ${ }^{1 *}$, Irwin L. Stoloff ${ }^{1 \#,}$, Antonio C. Simoes ${ }^{2}$ \\ ${ }^{1}$ Division of Medical Oncology, Thomas Jefferson School of Medicine, Philadelphia, USA \\ ${ }^{2}$ Division of Surgery, North Penn Hospital, Landsdale, USA \\ Email: *ajw.law160@gmail.com
}

How to cite this paper: Weiss, A.J., Stoloff, I.L. and Simoes, A.C. (2017) The Effect of Granulocyte Macrophage-Colony Stimulating Factor upon the Induction of Peripheral Blood Dendritic and Natural Killer Cells When Given Simultaneously with a Slow Continuous Doxorubicin Infusion. Journal of Cancer Therapy, 8, 637-644.

https://doi.org/10.4236/jct.2017.87054

Received: June 7, 2017

Accepted: July 15, 2017

Published: July 18, 2017

Copyright $(9) 2017$ by authors and Scientific Research Publishing Inc. This work is licensed under the Creative Commons Attribution International License (CC BY 4.0).

http://creativecommons.org/licenses/by/4.0/

\begin{abstract}
It has been demonstrated that it is safe to give Gm-Csf, together with Doxorubicin, by continuous intravenous infusion, thereby substantially increasing the amount of Doxorubicin administered to the average patient, and assuring that each patient receives an individually-determined safe and maximal amount of drug. It is known that Gm-Csf is a potent inducer of components that are major factors in an immunologic attack upon neoplasms. For that reason, we thought it would be worth evaluating in 4 patients' surface markers of dendritic precursor cells, dendritic cells [DC], and natural killer [NK] cells during the infusion. While there was substantial variation in individual responses, all 4 patients receiving $\mathrm{Gm}$-Csf developed persistent marked increases in cells with each of these markers. The significance of these findings will be discussed.
\end{abstract}

\section{Keywords}

Doxorubicin Infusion Dendritic, Killer Cells

\section{Introduction}

The combination of anti-cancer chemotherapy with an immuno-therapeutic attack upon the neoplasm is an active area of study at the present time. We have studied the effect of giving Granulocyte Macrophage-Colony Stimulating Factor 
[Gm-Csf] concurrently with Doxorubicin given by slow intravenous infusion. Doxorubicin did not prevent the stimulation of natural killer cell production and their precursors by Gm-Csf nor was any adverse effect upon the anti-tumor activity of Doxorubicin noted.

\section{Materials and Methods}

\subsection{Patient Selection}

Two of the patients had extensive metastatic carcinoma of the breast, one, 35 years old, primarily involving the liver and lung, and a few bony metastatic lesions, tumor stage M1; the other, 41 years old, had extensive hepatic and skin metastases, but no obvious bony metastases, either by bone scans or x ray, tumor stage M1. The third patient, a nine year old male, had a very large angiosarcoma, probably arising in the scapula, with no evidence of metastatic disease; tumor stage T3, N0, and M0. The fourth patient, a 22-year-old male, had a small cell anaplastic carcinoma, probably arising in the lung, with widespread pulmonary and hepatic metastases, and several small osteolytic lesions believed to be due to metastases; tumor stage M1. None of these patients had received prior anti-cancer chemotherapy, radiotherapy, or immunotherapy. Informed consent was obtained from all patients, and the protocols were approved by the pertinent institutional review boards.

\subsection{Course of Therapy}

Full details of the course received by these patients have been described in previous articles [1] [2]. All patients received $250 \mathrm{ucgm} / \mathrm{M}^{2}$ of Gm-Csfsc, beginning 2 days before the Doxorubicin infusion was started, and continuing throughout therapy. Doxorubicin, $8 \mathrm{mgm} / \mathrm{M}^{2}$ was given as a 24 hour infusion/ day. With all four patients, the peripheral W.B.C rapidly increased and the infusion was continued at this dose until the W.B.C fell to less than $7000 / \mathrm{ul}$, or platelet count fell to less than 25,000/ul.

1) Assay of monocytes and dendritic cells precursors

Forty $\mathrm{ml}$. of peripheral blood was drawn at each interval from patient \#1, 80 ml. of blood was drawn at each interval from patients 2, 3, and 4. Buffy coats were separated by Ficoll gradient ultracentrifugation and cell populations assayed using a B.D. flow cytometer. The following cell markers, believed to represent factors related to anti-tumor immunotherapy, were evaluated, CD1c [3] [4] [5] [6], as a dendritic cell marker, CD34 [7] [8] as a dendritic precursor cell marker, and CD56 [9] [10] as a natural killer cell marker. Fluorescent cell surface markers were obtained either from Becton Dickinson or from other sources selected by them. Peripheral cell counts were determined with a Coulter counter. Number of cells in the peripheral blood with monocytoid features was determined by a trained cytologist using $\mathrm{H}$ and $\mathrm{E}$ and/or geimsa stains Studies of patient's 2, 3, and 4 were performed as soon as blood was drawn, blood from patient \#1 was drawn, packed in ice, and processed 3 to 6 hours later. 
2) Results of this study are presented in Table 1.

It is recognized that the labels chosen for each of the groups are arbitrary and that multiple markers and that several sub-groups for each of these groups exist. It is believed that the markers chosen would best represent the chosen group. Despite the small sample size, it is our belief that the results indicate that the simultaneous administration of a potent anti-tumor chemo-therapeutic agent and an agent that induces an immunologic attack upon a tumor is feasible and may act synergistically against the neoplasm.

\section{Discussion}

The paths to anti-cancer immunotherapy are complex and our knowledge of its workings is incomplete. We do know, however that the mobilization of dendritic precursor cells, mature dendritic cells, and native killer cells are essential

Table 1. Effect of Gm-Csf on killer cells and their precursors when given a continuous infusion of Doxorubicin.

\begin{tabular}{|c|c|c|c|c|c|c|}
\hline & $\mathrm{Pt} \#$ & Pre Rx & $\begin{array}{c}1-2 \\
\text { Days of }\end{array}$ & $\begin{array}{c}5-8 \\
\text { Days of }\end{array}$ & $\begin{array}{c}1-2 \\
\text { Days Post }\end{array}$ & Total Dose \\
\hline & & Value & Infusion & Infusion & Infusion & Infusion $\mathrm{M}^{2}$ \\
\hline \multirow[t]{4}{*}{$\mathrm{WBC} / \mathrm{ct} / \mathrm{ul}$} & 1 & 4850 & 16,585 & 22,915 & 2150 & 104 \\
\hline & 2 & 6635 & 14,560 & 19,900 & 1800 & 128 \\
\hline & 3 & 14,330 & 21,000 & 29,900 & 1835 & 72 \\
\hline & 4 & 5130 & 13,355 & 14,270 & 950 & 128 \\
\hline Monocyte & 1 & 385 & 2955 & 4490 & 110 & \\
\hline \multirow[t]{3}{*}{$\mathrm{Ct} / \mathrm{ul}$} & 2 & 710 & 4400 & 7000 & 465 & \\
\hline & 3 & 1600 & 11,350 & 12,050 & 910 & \\
\hline & 4 & 370 & 1980 & 7750 & 330 & \\
\hline$\%$ Immature & 1 & 0 & 35 & 55 & 74 & \\
\hline \multirow[t]{3}{*}{ Monocytes } & 2 & 0 & 50 & 70 & 62 & \\
\hline & 3 & 6 & 49 & 55 & 87 & \\
\hline & 4 & 2 & 22 & 46 & 88 & \\
\hline Total CD34 & 1 & 4 & 334 & 773 & 43 & \\
\hline \multirow[t]{3}{*}{ Cells/ul } & 2 & 1 & 189 & 247 & 34 & \\
\hline & 3 & 11 & 606 & 677 & 177 & \\
\hline & 4 & 2 & 805 & 301 & 96 & \\
\hline Total Cd1c & 1 & 107 & 222 & 787 & 44 & \\
\hline \multirow[t]{3}{*}{ Cells/ul } & 2 & 84 & 589 & 623 & 21 & \\
\hline & 3 & 222 & 892 & 1409 & 16 & \\
\hline & 4 & 75 & 103 & 982 & 37 & \\
\hline TotalCD56 & 1 & 98 & 231 & 782 & 333 & \\
\hline \multirow[t]{3}{*}{ Cells/ul } & 2 & 22 & 44 & 288 & 106 & \\
\hline & 3 & 178 & 589 & 540 & 277 & \\
\hline & 4 & 49 & 379 & 811 & 87 & \\
\hline
\end{tabular}


components in one of these paths [11]. It is also recognized that Gm-Csf is a potent inducer of this process. We therefore thought it would be of value to determine whether Doxorubicin, given by slow intravenous infusion, would interfere with the effect of Gm-Csf on this pathway. The results presented in table one; however, indicate that Gm-Csf is capable of initiating a major immuno-stimulating pathway despite the presence of a significant blood level of Doxorubicin.

Until recently the simultaneous use of hematologic growth factors such as G-Csf and Gm-Csf with anti-cancer agents has been discouraged, primarily because of the marked increase in toxicity when either has been given with either 5-fluorouracil or topotecan [12] [13]. Recent studies however have demonstrated that these agents can be used safely with several anti-neoplastic drugs such as Doxorubicin, Ifosphamide, or vincristine [2] [3] [14] [15] [16] [17]. We have also found that 5-fluorouracil and F.U.D.R. can be given safely, provided that the dose of the fluorinated pyrimidine is substantially reduced. We have noticed significant anti-tumor activity when F.U.D.R. is given intra-arterially and the dose is reduced to $20 \%$ to $30 \%$ of the standard dose. [1] [14] [15].

The disadvantages of this protocol have been noted in a previous publication [1] [2], and primarily relate to the complexity of the procedure. Another possible disadvantage is that the slow infusion leads to the absence of high peak levels of Doxorubicin. This may allow neoplasms with an effective Doxorubicin efflux pump to survive [1] [2]. The fact that multiple studies have shown that the anti-tumor effect of Doxorubicin against many tumor types is independent of type of schedule negates this problem [18] [19] [20] [21]. The third possibility is that Gm-Csf stimulates the growth of the tumor or protects the tumor against the chemotherapeutic agent [22] [23]. Although this possibility has been raised, especially concerning hematologic neoplasms, we know of no reports that suggest that this is true. The possibility that the use of Gm-Csf increases the risk of cardiac toxicity has been shown to be untrue in this scenario since it has been noted that a large number of patients receiving between 600 and $1400 \mathrm{mgm} / \mathrm{M}^{2}$ of Doxorubicin using this protocol failed to show any sign of cardiomyopathy [1] [2]. However, this possibility must be considered when other combinations of biologic anti-tumor agents and agents such as Doxorubicin are considered. For example, it is known that the concurrent use of trastuzumab and Doxorubicin significantly increases the occurrence of cardiotoxicity. [24]. Several other tyrosine kinase inhibitors have a similar effect [25].

\section{Advantages}

1) The simultaneous of Gm-Csf with a specific anticancer agent such as Doxorubicin significantly increases the amount of Doxorubicin tolerated by the average patient [1] [2].

2) It permits the total dose of Doxorubicin [and other anti-tumor agents] [1] [2] received by the patient to be individually determined and not determined by a set protocol dose. The variation in dosage tolerated by various patients is a major impediment to using standard dosage schedules. 
3) Theoretically the simultaneous use of an immunologic attack with anti-cancer chemotherapy might act in a synergist manner against the neoplasm. Thus, fragments of dying neoplastic cells, providing dendritic cells with tumor specific antigens, are being presented in large numbers to immunologic competent cells such as NK and dendritic cells.

4) There is evidence that Gm-Csf may act independently as an anti-tumor agent against several types of neoplasms [26] [27].

It was not possible to directly determine the anti-tumor effect of the single course of Gm-Csf and Doxorubicin in any of the 4 patients for several reasons. All patients received further anti-cancer therapy and the interval between courses was too short to expect radiographic evidence of an anti-tumor effect, as all patients received further aggressive chemotherapy as soon as their hematologic parameters returned to normal [1] [2]. Subjectively, the patient with the angiosarcoma reported that his pain, which, before therapy had been severe, had almost totally disappeared. The breast cancer patient with bony metastases also reported marked pain relief as did the patient with the anaplastic carcinoma. This finding is commonly recognized as an indication of tumor necrosis. We have reported that repeated courses of infusional Gm-Csf with Doxorubicin, as well as similar courses utilizing Ifosphamide, or Vinorelbine have been very effective in tumor control [1] [2].

The dose of GM-Csf was arbitrarily chosen and may have been sub-optimal. It has been demonstrated that a much larger dose of $\mathrm{Gm}-\mathrm{Csf}\left[500 \mathrm{ugm} / \mathrm{M}^{2}\right]$ when given daily is well tolerated and is associated with a substantially greater increase in the number of leukocytes as compared to the 250 ugm daily dose [28]. This suggests that if we raise the dose to Gm-Csf the immune mediated antitumor effect may be enhanced. It is also been shown that other agents such as IL4, IL12, or IL21 when given with GM-Csf influences the effectiveness of the immunologic antitumor response [29] [30] [31]. This suggests that combining Gm-Csf with other immunologic agents may enhance the effect that we have seen. It is also possible that other cytokine would be more effective than Gm-Csf as an immunologic stimulant. This may be worth studying.

\section{Conclusions}

Four patients received Gm-Csf $250 \mathrm{ugm} / \mathrm{M}^{2}$ s.c. daily together with Doxorubicin $8 \mathrm{mgm} / \mathrm{M}^{2}$ given by continuous infusion until hematologic toxicity occurred. Cells believed to be involved in the anti-tumor immune responses were monitored using cell surface markers. These included CD34 cells as a tracer for DC progenitor cells, CD1c for dendritic cells, and CD56, as a tracer for Natural Killer cells. All these cells showed a rapid and marked rise. Thus, the number of CD34-labelled cells rose from an average of $4.5 / \mathrm{ul}$ to an average of 497 cells/ul, the number of CD1c labelled cells from 122/ul to 950/ul, and CD56 labelled cells from 88/ul to 605/ul. Mature monocyte counts markedly increased and immature monocytes and other very primitive nucleated cells, extremely rare before therapy, appeared in large numbers. These immature cells disappeared once the 
Gm-Csf was stopped. The average tolerated dose of Doxorubicin was $108 \mathrm{mgm} /$ $\mathrm{M}^{2}$.

The destruction of neoplastic cells with the ejection of tumor fragments into the peripheral blood in the presence of large number of dendritic and natural killer cells, therefore, may yield a substantial increase in the anti-tumor effectiveness of Doxorubicin and increase the potency of the body's anti-tumor immunologic defense mechanisms.

\section{References}

[1] Weiss, A.J. and Stoloff, I.L. (2015) Three Protocols Designed to Individualize and Maximize Anti-Cancer Drug Therapy. Journal of Cancer Therapy, 6, 1103-1113. https://doi.org/10.4236/jct.2015.612120

[2] Weiss, A.J. and Lackman R.D. (1997) Infusional Chemotherapy Combined with Hematopoetic Growth Factors Advantages and Limitations. American Journal of Clinical Oncology, 20, 63-66. https://doi.org/10.1097/00000421-199702000-00014

[3] MacDonald, K.P., Munster, D.J., Clark, G.J., Dzionek, A., Schmitz, J. and Hart, D.N. (2002) Characterization of Human Blood Dendritic Cell Subsets. Blood, 100, 4512 4520. https://doi.org/10.1182/blood-2001-11-0097

[4] Palucka, K. and Banchereau, J. (2012) Cancer Immunotherapy via Dendritic Cells. Nature Reviews Cancer, 12, 265-277. https://doi.org/10.1038/nrc3258

[5] Nizzoli, G., Krietsch, J., Weick, A., Steinfelder, S., Facciotti, F., Gruarin, P., Bianco, A., Steckel, B., Moro, M., Crosti, M., et al. (2013) Human CD1c+ Dendritic Cells Secrete High Levels of IL-12 and Potently Prime Cytotoxic T-Cell Responses. Blood, 122, 932-942. https://doi.org/10.1182/blood-2013-04-495424

[6] Breton, G., Lee, J., Zhou, Y.J., Schreiber, J.J., Keler, T., Puhr, S., Anandasabapathy, N., Schlesinger, S., Caskey, M., Liu, K. and Nussenzweig, M.C. (2015) Circulating Precursors of Human CD1c+ and CD141+ Dendritic Cells. Journal of Emergency Medicine, 212, 401. https://doi.org/10.1084/jem.20141441

[7] Morse, E., Anderson, P. and Caligiuri, M.A. (1996) Caligiuri Role of Interleukin-15 in the Development of Human CD56+ Natural Killer Cells from CD34+ Hematopoietic Progenitor Cells. Blood, 87, 2632-2640.

[8] Miller, J.S., McCullar, V., Punzel, M., Lemischka, I.R. and Moore, K.A. (1999) Single Adult Human CD34(+)/Lin-/CD38(-) Progenitors Give Rise to Natural Killer Cells, B-Lineage Cells, Dendritic Cells, and Myeloid Cells. Blood, 93, 96-106.

[9] Frey, M., Packianathan, N.B., Fehniger, T.A., Ross, M.E., Wang, W.C., Stewart, C.C., Caligiuri, M.A. and Evans, S.S. (1998) Differential Expression and Function of L-Selectin on CD56bright and CD56dim Natural Killer Cell Subsets. The Journal of Immunology, 161, 400-408.

[10] Cooper, M.A., Fehniger, T.A., Turner, S.C., Chen, K.S., Ghaheri, B.A., Ghayur, T., Carson, W.E. and Caligiuri, M.A. (2001) Human Natural Killer Cells: A Unique Innate Immunoregulatory Role for the CD56 (Bright) Subset. Blood, 97, 3146-3151. https://doi.org/10.1182/blood.V97.10.3146

[11] Colucci, F., Caligiuri, M.A. and Di Santo, J.P. (2003) What Does It Take to Make a Natural Killer? Nature Reviews Immunology, 3, 413-425. https://doi.org/10.1038/nri1088

[12] Meropol, N.J., Miller, L.L., Korn E.L., Braitman, L.E., MacDermott M.L. and Schuchter, L.M. (1992) Severed Myelosuppression Resulting from Concurrent Administration of Granulocyte Colony-Stimulating Factor and Cytotoxic Chemotherapy. Journal of 
the National Cancer Institute, 84, 1201-1203. https://doi.org/10.1093/jnci/84.15.1201

[13] Rowinsky, E.K., et al. (1992) Phase I and Pharmacologic Study of Topotecan, an Inhibitor of Topoisomerase I with Granulocyte Colony-Stimulating (G-CSF) Toxicologic Differences between Concurrent and Post Treatment G-CSF Administration. Journal of Clinical Oncology, 11, 284.

[14] Lokich, J. (1999) Single-Dose Granulocyte Colony-Stimulating Factor Concomitant with Multifractionated Dose Chemotherapy. A Strategy for Maintaining Dose Intensity Cancer Investigation, 17, 547-550. https://doi.org/10.3109/07357909909032865

[15] Müller, H.I., Nakchbandi, W., Chatzissavvidis, I. and Valek, V. (2001) Intra-Arterial Infusion of 5-Fluorouracil plus Granulocyte-Macrophage Colony-Stimulating Factor (GM-CSF) and Chemoembolization with Melphalan in the Treatment of Disseminated Colorectal Liver Metastases. European Journal of Surgical Oncology, 27, 652-661. https://doi.org/10.1053/ejso.2001.1193

[16] Ottman, O.G., Hoelzer, D., Gracien, E., Ganser, A., Kelly, K., et al. (1995) Concomitant Granulocyte Colony-Stimulating Factor and Induction Chemoradiotherapyin Adult Acute Lymphoblastic Leukemia A randomized Phase Three Trial. Blood, 444-450.

[17] Tessoulin, B., Thomare, P., Delande, E., Moynard, J., Gastinne, T., Moreau, A., Bossard, C., Mahé, B., Blin, N., Dubruille, V., Touzeau, C., Boudreault, J.S., Perrin, F., Lok, A., Guillaume, T., Garnier, A., Peterlin, P., Gallas, P., Chevallier, P. and Moreau, P. (2017) Carboplatin Instead of Cisplatin in Combination with Dexamethasone, High-Dose Cytarabine with or without Rituximab (DHAC+/-R) Is An Effective Treatment with Low Toxicity in Hodgkin's and Non-Hodgkin's Lymphoma. Annals of Hematology, 96, 943-950. https://doi.org/10.1007/s00277-017-2981-2

[18] Weiss, A.J., Metter, G.E., Fletcher, W.S., Wilson, W.L., Grage, T.B. and Ramirez, G. (1976) Studies of Adriamycin Using a Weekly Regime Demonstrating Its Clinical Effectiveness and Lack of Cardiac Toxicity. Cancer Treatment Reports, 60, 813-822.

[19] Starling, K.A., Berry, D.H., Britton, H.A., Humphrey, G.B., Vats, T. and Ragab, A.H. (1975) Three Dose Regimens of Adriamycin for Induction of Remission in Acute Leukemia in Children: A Southwest Oncology Group Study. Medical and Pediatric Oncology, 1, 271-276. https://doi.org/10.1002/mpo.2950010309

[20] Berrak, S.G., Ewer, M.S., Jaffe, N., Pearson, P., Ried, H., Zietz, H.A. and Benjamin, R.S. (2001) Doxorubicin Cardiotoxicity in Children: Reduced Incidence of Cardiac Dysfunction Associated with Continuous-Infusion Schedules. Oncology Reports, 8 , 611-614. https://doi.org/10.3892/or.8.3.611

[21] Torti, F.M., Bristow, M.R., Howes, A.E., Aston, D., Stockdale, F.E., Carter, S.K., Kohler, M., Brown, B.W.J. and Billingham, M.E. (1983) Reduced Cardiotoxicity of Doxorubicin Delivered on a Weekly Schedule. Assessment by Endomyocardial Biopsy. Annals of Internal Medicine, 99, 745-749. https://doi.org/10.7326/0003-4819-99-6-745

[22] Kowanetz, M., Wu, X., Lee, J., Tan, M., Hagenbeek, T., Qu, X., et al. (2010) Granulocyte-Colony Stimulating Factor Promotes Lung Metastasis through Mobilization of Ly6G+Ly6C+ Granulocytes. Proceedings of the National Academy of Sciences of the United States of America, 107, 21248-21255. https://doi.org/10.1073/pnas.1015855107

[23] Wang, J., Yao, L., Zhao, S., Zhang, X., Yin, J., Zhang, Y., et al. (2012) GranulocyteColony Stimulating Factor Promotes Proliferation, Migration and Invasion in Glioma Cells. Cancer Biology \& Therapy, 13, 389-400. 
https://doi.org/10.4161/cbt.19237

[24] Francis, S., Cheng, S., Arteaga, C. and Moslehi, J. (2004) Heart Failure and Breast Cancer Therapies: Moving towards Personalized Risk Assessment. Journal of the American Heart Association, 3, Article ID: e000780.

[25] Force, T., Krause, D.S. and Van, E.R.A. (2007) Molecular Mechanisms of Cardiotoxicity of Tyrosine Kinase Inhibition. Nature Reviews Cancer, 7, 332-344. https://doi.org/10.1038/nrc2106

[26] Wing, E.J., Magee, D.M., Whiteside, T.L., Kaplan, S.S. and Shadduck, R.K. (1989) Recombinent Human Granulocyte/Macrophage Colony-Stimulating Factor Enhances Monocyte Cytotoxicity and Secretion of Tumor Necrosis Factor Alpha and Interferon in Cancer Patients. Blood, 73, 643-646.

[27] Edmonson, J.H., Long, H.J., Kvols, L.K., Mann, B.S. and Grill, J.P. (1998) Can Molgramostim Enhance the Antitumor Effects of Cytotoxic Drugs in Patients with Advanced Sarcomas? Annals of Oncology, 8, 637-641. https://doi.org/10.1023/A:1008292010062

[28] Phillips, N., Jacobs, S., Stoller, R., Earle, M., Przepiorka, D. and Shadduck, R.K. (1989) Effect of Recombinant Human Granulocyte-Macrophage Colony-Stimulating Factor on Myelopoiesis in Patients with Refractory Metastatic Carcinoma. Blood, 74, 26-34.

[29] Miguel, A., Herrero, M.J., Sendra, L., Botella, R., Algás, R., Sánchez, M. and Aliño, S.F. (2013) Comparative Antitumor Effect among GM-CSF, IL-12 and GMCSF+IL-12 Genetically Modified Tumor Cell Vaccines. Cancer Gene Therapy, 20, 576-578. https://doi.org/10.1038/cgt.2013.54

[30] Sivori, S., Cantoni, C., Pasolini, E., Marcenaro, R., Conte, L. and Moretta, A. (2003) IL-21 Induces Both Rapid Maturation of Human CD34+ Cell Precursors towards NK Cells and Acquisition of Surface Killer Ig-Like Receptors. European Journal of Immunology, 33, 3439-3447. https://doi.org/10.1002/eji.200324533

[31] Hiasa, M., Abe, M., Nakano, A., Oda, A., Amou, H., Kido, S., Takeuchi, K., Kagawa, K., Yata, K., Hashimoto, T., Ozaki, S., Asaoka, K., Tanaka, E., Moriyama, K. and Matsumoto, T. (2009) GM-CSF and IL-4 Induce Dendritic Cell Differentiation and Disrupt Osteoclastogenesis through M-CSF Receptorshedding by Up-Regulation of TNF-Alpha Converting Enzyme (TACE). Blood, 114, 4517-4526. https://doi.org/10.1182/blood-2009-04-215020

\section{Scientific Research Publishing}

Submit or recommend next manuscript to SCIRP and we will provide best service for you:

Accepting pre-submission inquiries through Email, Facebook, LinkedIn, Twitter, etc. A wide selection of journals (inclusive of 9 subjects, more than 200 journals)

Providing 24-hour high-quality service

User-friendly online submission system

Fair and swift peer-review system

Efficient typesetting and proofreading procedure

Display of the result of downloads and visits, as well as the number of cited articles

Maximum dissemination of your research work

Submit your manuscript at: http://papersubmission.scirp.org/

Or contact jct@scirp.org 